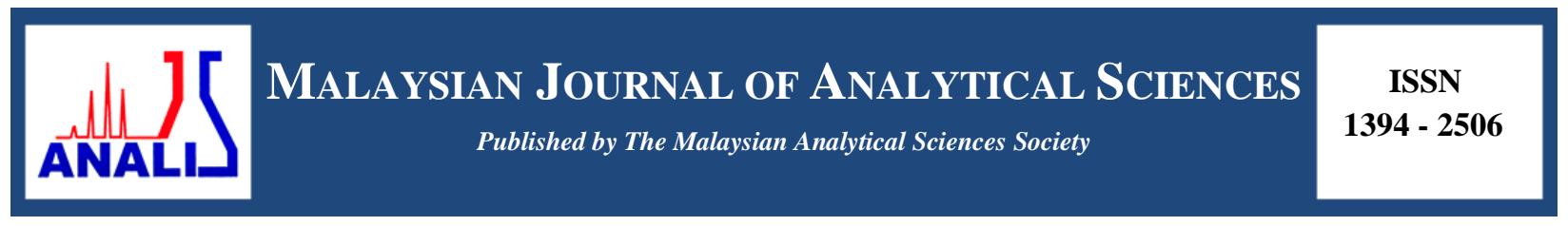

\title{
PESTICIDES RESIDUES IN AGRICULTURAL SOILS AND ITS HEALTH ASSESSMENT FOR HUMANS IN CAMERON HIGHLANDS, MALAYSIA
}

\author{
(Residu Racun Serangga dalam Tanah Pertanian dan Penilaian Kesihatan Terhadap Manusia \\ di Cameron Highlands, Malaysia)
}

\author{
Yang Farina ${ }^{1,2 *}$, Md Pauzi Abdullah ${ }^{1,2}$, Nusrat Bibi ${ }^{1,3}$, Wan Mohd Afiq Wan Mohd Khalik ${ }^{1}$ \\ ${ }^{1}$ School of Chemical Sciences and Food Technology, Faculty of Science and Technology, \\ Universiti Kebangsaan Malaysia, 43600 UKM Bangi, Selangor, Malaysia \\ ${ }^{2}$ Centre for Water Research and Analysis, Faculty of Science and Technology, \\ Universiti Kebangsaan Malaysia, 43600 UKM Bangi, Selangor, Malaysia \\ ${ }^{3}$ Department of Chemistry, Faculty of Science, \\ Sardar Bahadur Khan Women University, Quetta, Pakistan \\ *Corresponding author: farina@ukm.edu.my
}

Received: 16 May 2016; Accepted: 21 September 2016

\begin{abstract}
Soil contamination is one of the sensitive issue in agricultural region of Cameron Highlands, Malaysia, which is a largest vegetable producer. Organochlorine pesticides (OCPs), organophosphorus pesticides (OPPs) and pyrethroids pesticides (PYRs) concentrations were measured in 35 soil samples of selected crops. Among OCPs, the average concentration in the soil of these crops grown was in the order of cauliflowers > cabbage > broccoli > lettuce > celery > spinach > mustard, while for OPPs; spinach $>$ broccoli $>$ cabbage $>$ cauliflower $>$ celery $>$ lettuce $>$ mustard $>$ and for PYRs it was broccoli $>$ cabbage $>$ cauliflower $>$ spinach $>$ mustard $>$ celery $>$ lettuce. For risk assessment life time average daily dose (LADD) of $\Sigma$ OCPs, $\Sigma$ OPPs and $\Sigma$ PYRs for adults were calculated at $2.1 \times 10^{-7}-1 \times 10^{-6} \mathrm{mg} \mathrm{kg}^{-1} \mathrm{~d}^{-1}, 1.46 \times 10^{-11}-3.6 \times 10^{-10} \mathrm{mg} \mathrm{kg}^{-1} \mathrm{~d}^{-1}$ and $1.28 \times 10^{-12}-3.42 \times 10^{-12}$ $\mathrm{mg} \mathrm{kg}^{-1} \mathrm{~d}^{-1}$ meanwhile for children $5.3 \times 10^{-8}-2.7 \times 10^{-7} \mathrm{mg} \mathrm{kg}^{-1} \mathrm{~d}^{-1}, 3.8 \times 10^{-11}-9.4 \times 10^{-10} \mathrm{mg} \mathrm{kg}^{-1} \mathrm{~d}^{-1} \mathrm{and}^{-18} \times 10^{-12}-1.6 \mathrm{x}$ $10^{-10} \mathrm{mg} \mathrm{kg}^{-1} \mathrm{~d}^{-1}$. The hazard quotient (HQ) was $\leq 1$ indicating less health risks for humans. Principal Component Analysis (PCA) indicates a strong correlation of high pesticides residual concentration of the soil of crops (cauliflower, cabbage and broccoli) with soil properties ( $\mathrm{pH}$ and organic content) thus influencing its mobility and persistence whereas for other crops soil the decrease residual concentration might be related to crop type, rotation, roots exude, rhizosphere effect, or a rapid disappearance of pesticides after application.
\end{abstract}

Keywords: organochlorine, organophosphorus, pyrethroids, gas chromatography, multivariate analysis

\begin{abstract}
Abstrak
Pencemaran tanah merupakan salah satu daripada isu yang sensitif dalam kawasan pertanian di Cameron Highlands, Malaysia, di mana ianya merupakan kawasan pengeluar sayur yang terbesar di Malaysia. Kepekatan racun serangga organoklorin (OCPs), organofosforus (OPPs) dan piretroid (PYRs) telah diukur dalam 35 sampel tanah dari tanaman yang terpilih. Berikut merupakan tertib kepekatan OCPs dalam tanah dari tanaman kubis bunga $>$ kubis $>$ brokoli $>$ salad $>$ sederi $>$ bayam $>$ sawi, manakala untuk OPPs adalah bayam $>$ brokoli $>$ kubis $>$ kubis bunga $>$ saderi $>$ salad $>$ sawi dan untuk PYRs adalah brokoli $>$ kubis $>$ kubis bunga $>$ bayam $>$ sawi $>$ saderi $>$ salad. Bagi penilaian risiko purata jangka hayat dos harian (LADD) untuk $\Sigma$ OCPs, $\Sigma O P P s$ dan $\Sigma$ PYRs untuk dewasa adalah $2.1 \times 10^{-7}-1 \times 10^{-6} \mathrm{mg} \mathrm{kg}^{-1} \mathrm{~d}^{-1}, 1.46 \times 10^{-11}-3.6 \times 10^{-10} \mathrm{mg} \mathrm{kg}^{-1} \mathrm{~d}^{-1} \mathrm{dan} 1.28 \times 10^{-12}-3.42 \times 10^{-12}$ $\mathrm{mg} \mathrm{kg}^{-1} \mathrm{~d}^{-1}$, manakala kanak - kanak $5.3 \times 10^{-8}-2.7 \times 10^{-7} \mathrm{mg} \mathrm{kg}^{-1} \mathrm{~d}^{-1}, 3.8 \times 10^{-11}-9.4 \times 10^{-10} \mathrm{mg} \mathrm{kg}^{-1} \mathrm{~d}^{-1} \mathrm{dan}^{-1} 8.8 \times 10^{-12}-1.6 \mathrm{x}$ $10^{-10} \mathrm{mg} \mathrm{kg}^{-1} \mathrm{~d}^{-1}$. Darjah bahaya (HQ) adalah $\leq 1$ iaitu menjelaskan bahawa ianya kurang berisiko terhadap kesihatan manusia.
\end{abstract}


Analisis komponen utama (PCA) menunjukkan terdapat korelasi yang kuat untuk kepekatan residu racun serangga yang tinggi daripada tanah untuk tanaman (kubis bunga, kubis, dan brokoli) dengan ciri - ciri tanah ( $\mathrm{pH}$ dan kandungan organik) sekali gus mempengaruhi mobiliti dan pengekalannya manakala untuk tanah tanaman lain kepekatan residu berkurangan mungkin disebabkan oleh faktor yang berkaitan jenis tanaman, kitaran, rembesan akar - akar, kesan rezosfera, atau kehilangan racun yang cepat selepas penggunaannya.

Kata kunci: organoklorin, organofosforus, piretroid, kromatografi gas, analisis multivariat

\section{Introduction}

Pesticides pollution is extensively contaminating the environment due to its uncontrolled usage that degrades soil functions by degrading its biological activity and ability to remove pollutants that result in reduction of crop yield. Soil is regarded as a reservoir of xenobiotic that may be adsorbed to organic matter in soil and retained for decades or might be transported or degraded. Literature already proved that decomposition of these pesticides is less from soil to aquatic environment; therefore, it is even more threatening for future generations. Europe has already discussed the persistence behavior of pesticides in the Frame of Directive 91/414/EEC [1]. Soil system is relatively static and beyond human controls [1]. WHO/FAO [2] estimated 3 million cases of acute and severe pesticides poisoning with some 220,000 deaths and also reveals that largest human acute toxicity is caused by OPPs. One of the major soil contaminants are organophosphorus pesticides (OPPs), organochlorine pesticides (OCPs) and pyrethroids (PYRs). It can move in environment by volatilization, infiltration, runoff and transport along food chain $[3,4]$.

Organophosphorus pesticides are highly toxic; it has the ability to penetrate the cells of living organism. They are moderately polar and are mobile to leach and can be retained on vegetation that can affect the environment and food chain [5]. It not only effects the pests but also other microorganisms like fungi and bacteria that brings nutrients to the roots of plants so effecting the healthy interaction and replacing it with chemicals [6]. In contrast to OCPs, OPPs are less persistent but this behavior varies from few days to month and sometimes years depending upon the texture and organic content of soil [7]. Sorption, volatilization, solubility in water, hydrolysis or oxidation, photodegradation and biodegradation are some of the important factors dealing with the fate of OPPs in the environment [8].

PYRs are basically used for paralyzing insects and are less toxic and persistent than OCPs and OPPs. It is often used in combination with OPPs to enhance their insecticidal activity. It is considered to be the most widely used insecticide for vegetables farming in Malaysia and about $60 \%$ of farmers in use permethrin to control pests in the Cameron Highlands Malaysia [9].

Organochlorine pesticides are used worldwide due to its extensive insecticidal property and its use is prohibited due to high persistence (>10 years) and lipophilicity like DDT and $\beta-\mathrm{HCH}$ having higher stability and bio-accumulative property [10]. To understand the fate of OCPs globally it is necessary to know its fate in the tropical regions since they are considered as "net emissions" of OCPs to their "net sinks" Polar Regions. DDTs breakdown very slowly into its metabolites DDD and DDE. Among HCHs, the $\beta$-isomer is the most stable and persistent while $\alpha$-isomer is more volatile and dissipates quickly [11].

However, the use of these pesticides might cause alteration in local environment including death of farm animals, and also risks to human health [12]. Due to their properties of having hydrophobic, strong sorption to soil organic matter, and resistant to degradation such as DDT and HCH they might persist for longer period of time in environment. The human exposure might occur due to occupational exposure or direct consumption of these vegetables and in this case the inhalation, ingestion can be one of the main reason for exposure since agriculture is becoming the occupation and norm of the people in this region and this exposure might cause several toxicological health effects $[13,14]$.

The objective of this study is to identify and quantify the multi-residue of OCPs, OPPs and PYRs pesticides in soils of selected vegetables on the basis of its wide distribution and economic importance in agricultural region of Malaysia, Cameron Highlands and also to evaluate its correlation with physiochemical properties since the 
degradation of pesticides depends upon the microbiological, physical and chemical properties while the sorption depends upon the organic content of soil and its $\mathrm{pH}$ because of its effect on soil properties such as electric charge and ionic strength [15]. The third objective is to access human health risks associated with soil contamination.

\section{Chemicals}

\section{Materials and Methods}

Pesticides standards were obtained from Dr. Ehrenstorfer (Augsberg, Germany) with highest purity certificate. Individual pesticides stock solution of $1000 \mathrm{ppm}$ was prepared in acetone and stored in glass bottles at $<-16{ }^{\circ} \mathrm{C}$. Working pesticides mixture solution was prepared from stock solution and stored at $4{ }^{\circ} \mathrm{C}$. Acetone, Hexane, ethyl acetate and anhydrous sodium sulphate of analytical grade were from Merck (Darmstadt, Germany and Friendmann Schmidt Chemical). Combo SPE Florisil (500 mg $6 \mathrm{~mL}^{-1}$ ) packed was obtained from Restek (USA). The rotary evaporator (model A 1000s, Eyela), Soxhlet apparatus (Acott Lab Supplies Sdn. Bhd., Malaysia), Cellulose extraction thimbles with dimension $30 \mathrm{~mm} \times 80 \mathrm{~mm}$ (Whatmann, England) and laboratory test sieve (Endecotts Limited, England) were used in the present study.

\section{Sample collection and preparation}

Cameron Highlands is the second largest producer of vegetables to Malaysia. Thus, it remarkably very important agricultural and environmentally sensitive area for Malaysia. It is situated in Pahang state having an estimated area of $712 \mathrm{~km}^{2}$. Its location lies between $04^{\circ} 20^{\prime} \mathrm{N}-4^{\circ} 37^{\prime} \mathrm{N}$ and $101^{\circ} 20^{\prime}-101^{\circ} 36^{\prime} \mathrm{E}$ and its altitude is between $1280-1830 \mathrm{~m}$ above sea level. Average daily temperature and annual rainfall is between $14-21^{\circ} \mathrm{C}$ and $2800 \mathrm{~mm}$.

In this study, seven different sampling sites were chosen as shown in Figure 1. The distance between station to station is $5 \mathrm{~km} \mathrm{Kg}$ Raja - Tanah Rata, $13 \mathrm{~km}$ (Tanah Rata - Telom), $19.3 \mathrm{~km}$ (Telom - Brinchang), $4 \mathrm{~km}$ Brinchang - Telom), $8 \mathrm{~km}$ (Tanah Rata - Habu) and $3 \mathrm{~km}$ (Habu - Ringlet). The spraying pattern varies at each sampling points during both wet and dry seasons. About $64 \%$ of farmers spray more frequently every 7 - 9 days. However, during the wet seasons, the spraying pattern is even more frequent of about $4-6$ days between each spraying. The highest being of $1-3$ days' interval recorded at upper part of the valley. High humidity and continuous cultivation caused the contamination of river in highland by OCPs and OPPs due to enormous use in plant protection $[16,17]$.

A total of 35 soil samples $(0-10 \mathrm{~cm})$ soil layer, consisting of three soil samples of approximately $1-2 \mathrm{~kg}$ for each corresponding vegetable were taken randomly from the cultivated horizon of seven different sites of agricultural region (Figure 1) by a stainless steel scoop wrapped in aluminum foil and placed in polyethylene bags stored in dark and transported to laboratory as soon as possible. These soil samples differed in terms of soil properties and land usage. Each soil sample was divided into two parts, one for pesticide analysis and other for soil geochemical properties. Samples were registered with sample location and site description. Soil samples were placed in amber glass bottles and stored at $-18{ }^{\circ} \mathrm{C}$ until extraction. Soil samples were frozen, oven dried and homogenized by 80 mesh steel sieve.

Soil samples were frozen, oven dried and homogenized by 80-mesh steel sieve. A $15 \mathrm{~g}$ of dried weight sample was spiked by $1 \mathrm{~mL}$ of mixture of pesticides solution and was placed in thimble along with $6-7 \mathrm{~g}$ of anhydrous sodium sulphate and extracted with $150 \mathrm{~mL}$ of acetone: hexane (1:1) in soxhlet apparatus for 4 hours. The extract was concentrated to $3 \mathrm{~mL}$ by rotary evaporator $\left(40{ }^{\circ} \mathrm{C}\right)$. The cleanup was done by Florisil $\left(500 \mathrm{mg} 6 \mathrm{~mL}^{-1}\right)$ priory conditioned by $5 \mathrm{~mL}$ of methanol and the sorbent were not allowed to dry during conditioning and loading steps. Sample loading was performed at $5 \mathrm{~mL} \mathrm{~min}^{-1}$ column and eluted with ethylacetate: hexane (1:1) and the final extract was concentrated by nitrogen gas up to $1 \mathrm{~mL}$ and analyzed by gas chromatography - electron capture detector (GC-ECD). 


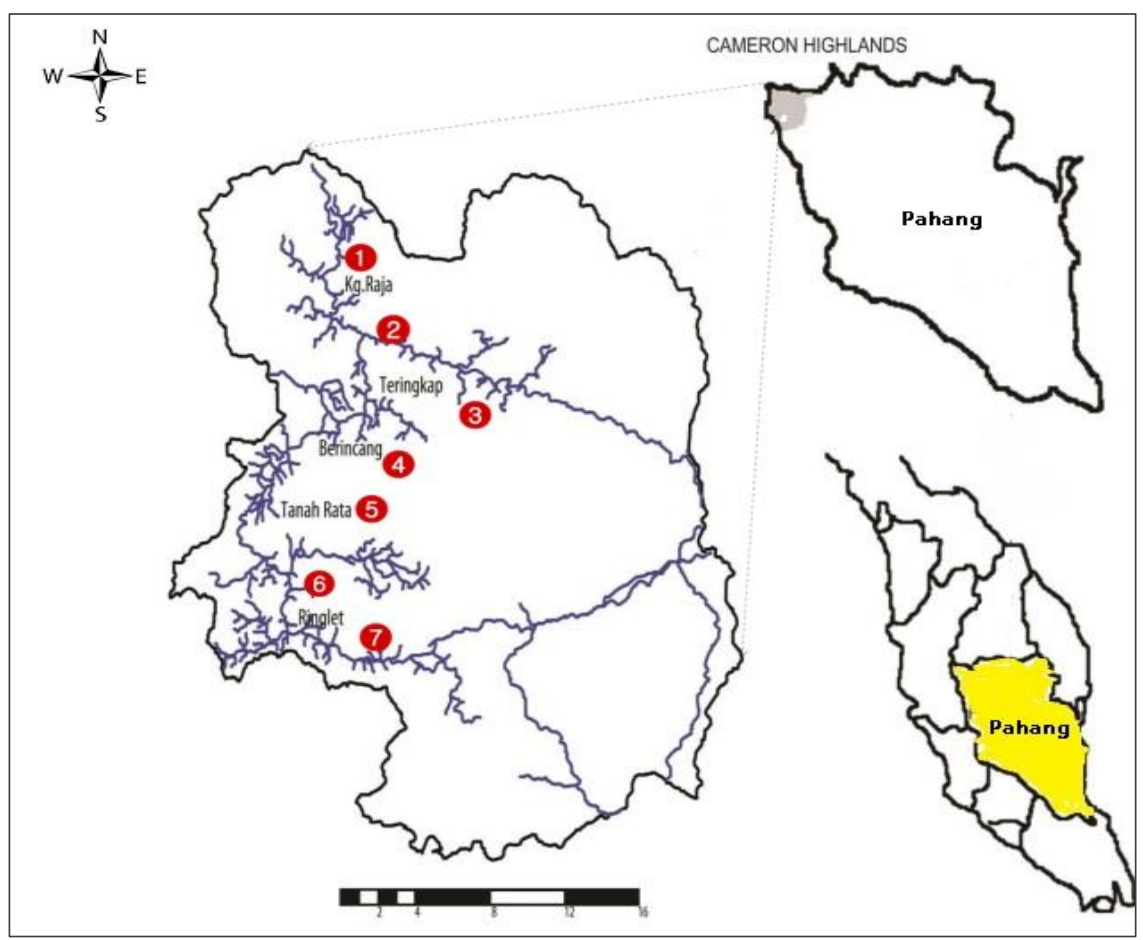

Figure 1. Map showing study area and sampling location (label in red)

Human exposure to pesticides and the consequent health risks associated with it was estimated by the equation given by USEPA. In this study the life time average daily dose (LADD) of pesticides and hazard quotient (HQ) were calculated through soil ingestion according to US Environmental Protection Agency and Agency for Toxic Substances and Disease Registry [13,18,19]. The following equations 1 and 2 were used for estimating the LADD and HQ:

$$
\begin{aligned}
& \text { LADD } \left.\left(\mathrm{mg} \mathrm{kg}^{-1} \text { day }^{-1}\right)=(\mathrm{Cs} \times \mathrm{IRF} \text { X EF x ED }) / \mathrm{BW} \times \mathrm{AT}\right) \\
& \text { Hazard Quotient }(\mathrm{HQ})=\mathrm{LADD} / \mathrm{RFD}
\end{aligned}
$$

where $\mathrm{Cs}$ is the pollutant concentration in soil $\left(\mathrm{mg} \mathrm{kg}^{-1}\right)$, IR is soil ingestion rate (100 $\mathrm{mg} \mathrm{d}^{-1}$ for adults) [18], $\mathrm{F}$ is the conversion factor unit, $\mathrm{EF}$ is the exposure frequency (365 days/year), ED is the lifetime exposure duration (adults, 70 years; children, 12 years), BW is a body weight (adults, $70 \mathrm{~kg}$; children, $27 \mathrm{~kg}$ ) [18] and AT is the averaging time for carcinogens (EF x ED). RFD is the reference dose for particular compound in $\mathrm{mg} / \mathrm{kg} \mathrm{day}{ }^{-1}$ [13].

Soil $\mathrm{pH}$ was determined from water: soil $(5: 1)$ slurry by using soil $\mathrm{pH}$ meter. The organic matter content was determined by loss on ignition in which soil sample were first dried in oven at $104{ }^{\circ} \mathrm{C}$ for 24 hours and then the organic matter was combusted to ash and $\mathrm{CO}_{2}$ at temperature between $500-550{ }^{\circ} \mathrm{C}$ and the loss on ignition (LOI) was calculated by the following equation 3 [20].

$$
\mathrm{LOI}_{550}=\left[\left(\mathrm{DW}_{105}-\mathrm{DW}_{550}\right) / \mathrm{DW}_{105}\right] \times 100
$$

Particle size was used to evaluate the soil texture. USDA classification scheme was used as reference in particle size analysis. The dry method of sieve analysis was performed by weighing $500 \mathrm{~g}$ of oven dried sample and separated 
through three size of fractions $(<0.05 \mathrm{~mm}, 0.05 \mathrm{~mm}-2 \mathrm{~mm}$ and $2 \mathrm{~mm})$. The empty sieve and pan was weighed to $0.1 \mathrm{~g}$ and the mass of soil size of each fraction was weighed and mass fraction was calculated.

\section{Analytical quality control}

Pesticides concentrations were determined by external standard method using the peak areas of samples and five levels calibration curves of the standards. The peak was identified by their respective retention times of each standard. Cross contamination of all solvents and chemicals was checked by running a procedural blank. Linearity was estimated by an external calibration curve which was constructed at 5 calibration points by triplicate analysis ranging from $0.5-3 \mathrm{mg} \mathrm{L}^{-1}$. These calibration curves were linear with $r^{2}$ value ranging from $0.990-0.995$. The precision was established by triplicate analysis and extraction during accuracy studies. Acceptable precision was a value less than $20 \%$.

The recovery was calculated at two fortification levels with addition of known quantity of standard. For this purpose, pesticide free samples were collected from the remote areas for spiked samples. Samples were spiked at concentration of $1 \mathrm{mg} \mathrm{kg}^{-1}$ and $0.5 \mathrm{mg} \mathrm{kg}^{-1}$ with a pesticide mixture. The spiked and non-spiked samples were processed separately as real samples in triplicate. The average recoveries of OCPs were within a range $68 \%-98 \%$, $( \pm 2.37 \%-16.5 \%)$, OPPs ranges between $75 \%-103 \%,( \pm 1.1 \%-10.7 \%)$ and SPY ranges between $68 \%-95 \%,( \pm$ $1 \%-7 \%$ ), respectively. The limit of detection and limit of quantification were calculated according to the IUPAC recommendation, three times the standard deviation of seven soil samples spiked at lowest concentration. The limit of detection (LOD) for analytes ranges between $0.04 \mathrm{ng} \mathrm{g}^{-1}-0.4 \mathrm{ng} \mathrm{g}^{-1}, 0.8 \mathrm{ng} \mathrm{g}^{-1}-1.8 \mathrm{ng} \mathrm{g}^{-1}$ and from $3.8 \mathrm{ng} \mathrm{g}^{-1}-$ $5 \mathrm{ng} \mathrm{g}^{-1}$ for OCPs, OPPs and PYRs, respectively. Multivariate statistical analysis namely principle component analysis was used for interpretation of data (Minitab Inc., State college, USA).

\section{Instrumentation}

Varian chrome pack CP-3800 gas chromatography was used to analyze pesticides residue content. The instrument equipped with ${ }^{63} \mathrm{Ni}$ electron capture detector and a $30 \mathrm{~m}$ x $0.32 \mathrm{~mm}$ i.d $(0.25 \mu \mathrm{m}$ film thickness $)$, HP-MS 5ms fused silica capillary column. Nitrogen gas $(99.99 \%)$ was used as a carrier at a flow rate of $1.5 \mathrm{~mL} \mathrm{~min}{ }^{-1}$. Oven temperature was kept at $90{ }^{\circ} \mathrm{C}$ for $1 \mathrm{~min}$ than increased to $170{ }^{\circ} \mathrm{C}$ at a rate of $3.5^{\circ} \mathrm{C} \mathrm{min}{ }^{-1}$ and finally to $280{ }^{\circ} \mathrm{C}$ at rate of $5{ }^{\circ} \mathrm{C} / \mathrm{min}$. The injector and the detector temperature were adjusted to $250{ }^{\circ} \mathrm{C}$ and $300{ }^{\circ} \mathrm{C}$. An amount of $2 \mu \mathrm{L}$ of each sample was injected to GC-ECD for separation and quantitative analysis.

\section{Concentration of organochlorine pesticides}

\section{Results and Discussion}

The sum of $\Sigma$ OCPs concentration were $44.1 \pm 19.3 \mu \mathrm{g} \mathrm{kg}^{-1}, 49.1 \pm 19.0 \mu \mathrm{g} \mathrm{kg}^{-1}, 25.8 \pm 18.3 \mu \mathrm{g} \mathrm{kg}^{-1}, 28.4 \pm 19.4 \mu \mathrm{g} \mathrm{kg}^{-1}$, $28.1 \pm 18.5 \mu \mathrm{g} \mathrm{kg}^{-1}, 37.2 \pm 18.4 \mu \mathrm{g} \mathrm{kg}^{-1}, 13.7 \pm 16.3 \mu \mathrm{g} \mathrm{kg}{ }^{-1}$ in soils of crops cabbage, cauliflower, spinach, celery, lettuce, broccoli and mustard (Table 1). The total concentration of OCPs (sum of $\alpha-\mathrm{HCH}, \beta-\mathrm{HCH} \gamma-\mathrm{HCH}$, DDE, DDD, DDT, endosulfan) in the soil of these crops ranges as ND - $13.3 \mu \mathrm{g} \mathrm{kg}^{-1}$ in cabbage, cauliflower (ND - 13.3 $\mu \mathrm{g} \mathrm{kg}^{-1}$ ), spinach (ND $-55.3 \mu \mathrm{g} \mathrm{kg}^{-1}$, celery (ND $-6.6 \mu \mathrm{gg}^{-1}$ ), lettuce (ND $-8 \mu \mathrm{g} \mathrm{kg}^{-1}$ ), broccoli (ND $-4 \mu \mathrm{g} \mathrm{kg}^{-1}$ ), and mustard (ND $-3.3 \mu \mathrm{g} \mathrm{kg}^{-1}$ ). The observed trend of concentration of studied OCPs in these studies were $\gamma-\mathrm{HCH}$ $(23.9 \%)>$ endosulfan $(21.7 \%)>\operatorname{DDE}(18.1 \%)>\operatorname{DDD}(11.7 \%)>\alpha-\mathrm{HCH}(11.5 \%)>\beta-\mathrm{HCH}(7.7 \%)>\mathrm{DDT}(4.5 \%)$. The OCPs concentration in the soils of these crops decreases in the following order cauliflowers $>$ cabbage $>$ broccoli $>$ celery $>$ lettuce $>$ mustard. Among HCHs the concentration decreases in the following order $\gamma-\mathrm{HCH}>\alpha-\mathrm{HCH}>\beta$ $\mathrm{HCH}$. This might be due to some new inputs for $\mathrm{HCHs}$ or its slow degradation rate. DDTs ranges as DDE > DDD > DDT showing its degradation and historical inputs. This high concentration of DDE shows the aerobic environment in surface soil [21] and this also shows that the degradation of the DDT is related to the physical property like $\mathrm{pH}$ in this case found to be higher (8.5) as an average for the soil of brassica leafy vegetables. Thus, its enhancing the degradation factor in soil of these crops. The $\Sigma$ OCPs concentration observed in these studies were compared with other agriculture sites such as Mexico (36.91 - $\left.389.31 \mu \mathrm{g} \mathrm{kg}^{-1}\right)$ and $\left(5.2-316.4 \mu \mathrm{g} \mathrm{kg}^{-1}\right)$ [10, 21], China $(7.82-765$ $\left.\mu \mathrm{g} \mathrm{kg}^{-1}\right)$ [11] and India $\left(1231-1734 \mathrm{ng} \mathrm{g}^{-1}\right)$ [2]. 
Table 1. Concentration of OCPs in agricultural soil of Cameron Highlands

\begin{tabular}{lccccccc}
\hline \multirow{2}{*}{ Compounds } & \multicolumn{7}{c}{ Concentration in Soil Sample of Vegetables $\left(\boldsymbol{\mu g} \mathbf{~ k g}^{-\mathbf{1}}\right)$} \\
\cline { 2 - 7 } & Cabbage & Cauliflower & Spinach & Celery & Lettuce & Broccoli & Mustard \\
\hline$\alpha-\mathrm{HCH}$ & $2.6 \pm 0.4$ & $13.3 \pm 0.8$ & $4.66 \pm 0.4$ & ND & ND & $4.6 \pm 0.5$ & $1.3 \pm 2.2$ \\
$\beta-\mathrm{HCH}$ & $3.3 \pm 5.2$ & $4.0 \pm 7.4$ & $2.6 \pm 1.2$ & ND & ND & $4.0 \pm 5.8$ & $4.0 \pm 1.9$ \\
$\gamma-\mathrm{HCH}$ & $6.0 \pm 1.8$ & $6.6 \pm 1.5$ & $6.6 \pm 1.9$ & $10.6 \pm 7.5$ & $6.6 \pm 2.4$ & $12.6 \pm 1.8$ & $6 \pm 6.42$ \\
$\mathrm{DDE}$ & $10.6 \pm 5.5$ & $10.6 \pm 1.9$ & $0.6 \pm 2.9$ & $8.6 \pm 2.4$ & $6.6 \pm 1.4$ & $2.0 \pm 2.4$ & $1.8 \pm 4.5$ \\
$\mathrm{DDD}$ & $9.3 \pm 0.7$ & $2.6 \pm 1.6$ & $2.0 \pm 0.1$ & $0.6 \pm 4.1$ & $6.6 \pm 1.2$ & $5.13 \pm 2.8$ & $0.6 \pm 1.2$ \\
$\mathrm{DDT}$ & $2.0 \pm 4.9$ & $2.0 \pm 5.1 .0$ & $2.0 \pm 10.9$ & $0.6 \pm 3.4$ & $1.3 \pm 8.7$ & $2.3 \pm 2.4$ & $\mathrm{ND}$ \\
Endosulfan & $10 \pm 0.7$ & $10 \pm 1.0$ & $7.3 \pm 0.8$ & $8.0 \pm 2.5$ & $7.0 \pm 4.8$ & $6.6 \pm 2.7$ & $\mathrm{ND}$ \\
$\Sigma$ OCPs & $44 \pm 19.3$ & $49.1 \pm 19$ & $25.76 \pm 18.3$ & $28.4 \pm 19.9$ & $28.1 \pm 18.5$ & $37.23 \pm 18.4$ & $13.7 \pm 16.3$ \\
\hline
\end{tabular}

$\beta$-HCH is the most stable, symmetrical structure and does not degrade easily in soil so in degradation process other $\mathrm{HCH}$ isomers will convert back to $\beta$-isomer and in soil its concentration will keep on increasing during degradation process that is why in many studies the ratio of $\beta / \alpha+\gamma$ is used to identify the historical pollution sources. If $\beta / \alpha+\gamma-$ $\mathrm{HCH}$ is higher than 0.5 would mean that it is due to historical pollution and if less than 0.5 would mean new sources has been introduced [3]. In current studies the majority of soil samples of their respective vegetables showed negative values indicating that the new sources accounted more for $\mathrm{HCH}$ pollution. This indicates the importance of pesticides spraying method, wind dispersion, leaching, wash out and volatilization that accounts for $80-90 \%$ of $\mathrm{HCH}$ from other farms to natural farms which is enhanced at high temperature, humidity, and intense solar radiation in tropical regions $[11,22,23]$.

In the case of DDTs, DDE/DDT the ratio was higher than 1 . The value for DDT $>1$ indicating its historical inputs or its degradation by microbial activity or by enzymes secreted by root exudates or it can be due to high temperature [24]. The spatial distribution analysis of OCPs was investigated. The DDTs values were higher at Kuala Terla station ranging from $11-40 \mu \mathrm{g} \mathrm{kg}^{-1}$. The maximum value at Kuala Terla station arises due to aerobic metabolites DDE of DDT. This results might be because of past usage of DDT in the agricultural area. The spatial distribution of HCHs and DDTs were not same at all sites. At seven sampling sites the sequence pattern for DDTs family were DDE> DDD> DDT. For HCH concentrations, the highest HCHs were found at Brinchang ranging from $1.3-26.6 \mu \mathrm{g} \mathrm{kg}^{-1}$. This maximum value arises due to the presence of $\beta-\mathrm{HCH}$ the most stable isomer of $\mathrm{HCH}$ indicating the past usage of $\mathrm{HCH}$ at this site. The highest endosulfan concentration was found at Kuala Terla of about $5 \mu \mathrm{g} \mathrm{kg}^{-1}$. Among all sites, the Kuala Terla site seems to be most polluted by the OCPs indicating an extensive agricultural activity in this region and the illiteracy of the farmers also contributing to it. The lowest OCPs concentration was found at Habu station.

\section{Human health risk assessment of OCPs}

Health assessment was based on the assumption that human beings might be exposed to pesticides contaminated soil through ingestion, dermal contact or inhalation. The study area is an agricultural area so the farmers might be at great risk and since the compounds are persistent and hydrophobic so they would have higher affinity with soil particles. Therefore, the LADD of pesticides and HQ were calculated through soil ingestion $[13,18,19]$ (Table 2). In this study we included adults of 70-year-old and children of 12 years of age exposed for all the days in a year during their life span. The estimated LADD of total OCPs for adults and children through soil ranged between $2.1 \times 10^{-8}-$ $1 \times 10^{-7} \mathrm{mg} \mathrm{kg}^{-1} \mathrm{~d}^{-1}$ and $5.3 \times 10^{-8}-2.7 \times 10^{-7} \mathrm{mg} \mathrm{kg}^{-1} \mathrm{~d}^{-1}$ with the mean values as $5.2 \times 10^{-7} \mathrm{mg} \mathrm{kg}^{-1} \mathrm{~d}^{-1}$ and $1.3 \times 10^{-7}$ $\mathrm{mg} \mathrm{kg}^{-1} \mathrm{~d}^{-1}$ (Table 2). HQ for human adults for sum of OCPs are $6.7 \times 10^{-5}, 8 \times 10^{-6}, 1.6 \times 10^{-5}$ and for children was 3 $\times 10^{-5}, 4 \times 10^{-6}, 8.6 \times 10^{-6}$ (Table 3 ) which were lower than the acceptable risk levels. Thus, it indicated that the daily dose is below the proposed guidelines of USEPA 2012 [13]. 
Table 2. Concentration of OCPs and its life time average daily dose for humans through soil ingestion

\begin{tabular}{|c|c|c|c|c|c|c|}
\hline \multirow{3}{*}{ Compounds } & \multirow{2}{*}{\multicolumn{2}{|c|}{$\begin{array}{c}\text { Concentration } \\
\left(\mu \mathrm{g} \mathrm{kg}^{-1}\right)\end{array}$}} & \multicolumn{4}{|c|}{$\left(\right.$ LADD mg kg-1 $\left.\mathbf{d}^{-1}\right)$} \\
\hline & & & \multicolumn{2}{|l|}{ Adults } & \multicolumn{2}{|l|}{ Children } \\
\hline & Range & Mean & Range & Mean & Range & Mean \\
\hline$\alpha-\mathrm{HCH}$ & $2.6-13.3$ & 3.8 & $3.7 \times 10^{-9}-1.9 \times 10^{-8}$ & $5.4 \times 10^{-8}$ & $1.9 \times 10^{-8}-9.8 \times 10^{-8}$ & $2.8 \times 10^{-8}$ \\
\hline$\beta-\mathrm{HCH}$ & $0.6-4$ & 2.5 & $8.5 \times 10^{-10}-5.7 \times 10^{-9}$ & $3.6 \times 10^{-8}$ & $4.4 \times 10^{-9}-2.9 \times 10^{-8}$ & $1.9 \times 10^{-8}$ \\
\hline$\gamma-\mathrm{HCH}$ & $3.3-12.6$ & 7.8 & $4.7 \times 10^{-9}-1.8 \times 10^{-7}$ & $1 \times 10^{-7}$ & $2.4 \times 10^{-8}-9.3 \times 10^{-8}$ & $5.7 \times 10^{-8}$ \\
\hline DDE & $2-17.3$ & 6.0 & $2.8 \times 10^{-9}-2.5 \times 10^{-8}$ & $8.5 \times 10^{-8}$ & $1.4 \times 10^{-8}-4.8 \times 10^{-8}$ & $4.4 \times 10^{-8}$ \\
\hline DDD & $0.6-9.3$ & 3.8 & $8.6 \times 10^{-10}-1.3 \times 10^{-8}$ & $5.5 \times 10^{-8}$ & $4.4 \times 10^{-9}-6.8 \times 10^{-8}$ & $2.8 \times 10^{-8}$ \\
\hline DDT & $2-6.6$ & 1.5 & $2.8 \times 10^{-9}-9.4 \times 10^{-9}$ & $2 \times 10^{-8}$ & $1.5 \times 10^{-8}-1.2 \times 10^{-7}$ & $1.0 \times 10^{-8}$ \\
\hline Endosulfan & $3.3-10$ & 7.0 & $4.7 \times 10^{-9}-1.4 \times 10^{-8}$ & $1 \times 10^{-8}$ & $4.4 \times 10^{-9}-1.2 \times 10^{-7}$ & $5.0 \times 10^{-8}$ \\
\hline Total OCPs & $14.4-73.1$ & 32.4 & $2.1 \times 10^{-8}-1.0 \times 10^{-7}$ & $4.6 \times 10^{-7}$ & $5.3 \times 10^{-8}-2.7 \times 10^{-7}$ & $2.4 \times 10^{-7}$ \\
\hline
\end{tabular}

Table 3. Hazard quotients to humans due to OCPs

\begin{tabular}{lcccccl}
\hline \multirow{2}{*}{ Pesticide } & $\begin{array}{c}\text { Reference dose } \\
\left(\mathbf{m g ~ k g}^{-1}\right)\end{array}$ & \multicolumn{2}{c}{ LADD $\left(\mathbf{m g ~ k g}^{-1} \mathbf{d}^{-\mathbf{1}}\right)$} & \multicolumn{2}{c}{ Hazard Quotient } & \multirow{2}{*}{ Health risk } \\
\cline { 3 - 6 } & $3 \times 10^{-3}$ & $2.4 \times 10^{-7}$ & $1 \times 10^{-7}$ & $6.7 \times 10^{-5}$ & $3 \times 10^{-5}$ & No \\
\hline$\Sigma$ HCHs & $2 \times 10^{-2}$ & $1.6 \times 10^{-7}$ & $8.3 \times 10^{-8}$ & $8 \times 10^{-6}$ & $4 \times 10^{-6}$ & No \\
$\Sigma$ DDTs & $6 \times 10^{-3}$ & $1.0 \times 10^{-8}$ & $5 \times 10^{-8}$ & $1.6 \times 10^{-5}$ & $8.6 \times 10^{-6}$ & No \\
Endosulfan & & & & &
\end{tabular}

\section{Concentration of organophosphorus and pyrethroids}

The sum of $\Sigma$ OPPs concentration were $45.1 \pm 7.2 \mu \mathrm{gkg}^{-1}, 34.9 \pm 10.3 \mu \mathrm{gkg}^{-1}, 65.8 \pm 2.3 \mu \mathrm{gkg}^{-1}, 22.7 \pm 19.8 \mu \mathrm{g} \mathrm{kg}^{-1}$, $15.5 \pm 16.4 \mu \mathrm{g} \mathrm{kg}^{-1}, 15.5 \pm 57.6 \mu \mathrm{g} \mathrm{kg}^{-1}, 14.7 \pm 18.9 \mu \mathrm{g} \mathrm{kg}^{-1}$ in the soil of crops cabbage, cauliflower, spinach, celery, lettuce, broccoli and mustard (Table 4). The sum of total concentration of OPPs (dimethoate, diazinon, chlorpyriphos, malathion, parathion methyl, parathion ethyl) in the soil of these crops ranges as ND-20 $\mu \mathrm{g} \mathrm{kg}^{-1}$ in cabbage, ND - $26 \mu \mathrm{g} \mathrm{kg}^{-1}$ in brocolli, $0.2-8 \mu \mathrm{g} \mathrm{kg}-1$ in celery, ND $-20 \mu \mathrm{g} \mathrm{kg}^{-1}$ in spinach, ND $-8 \mu \mathrm{g} \mathrm{kg}^{-1}$ in lettuce, and ND $-3.3 \mu \mathrm{g} \mathrm{kg}^{-1}$ in mustard. The OPPs concentration in these soil crops decreases in the following order spinach > broccoli > cabbage > cauliflower > celery > lettuce > mustard. This shows the same trend as that of OCPs except the spinach soil indicating that loose structure of soil of these vegetables might decrease the concentration of pesticides due to leaching or via exposure of these plots to the rainfall and since this part has a tropical climate so the decrease in concentration might be due to high temperature, moisture and intense microbial activity [17]. The observation of pesticides residue for spinach soil is highly contaminated by OPPs and mustard soils the least which might be due to the cultivation process of these crops or the type of irrigation system. The observed trend of concentration of studied OPPs in these studies were parathion ethyl $(25.3 \%)>$ dimethoate $(23.8 \%)>$ diazinon $(21 \%)>$ malathion $(14.3 \%)>$ chlorpyriphos $(13.3 \%)>$ parathion methyl $(2.2 \%)$. The slight high concentration of OPPs as compared to OCPs in the soil of these crops might be because these vegetables are more susceptible towards the insects or due to easily degradation of OPPs that's is why these are applied frequently and there can be a possibility that insects have developed a low level of resistance towards these pesticides. These OPPs concentration was higher than other studies in Cameron Highland $\left(<0.01-0.06 \mathrm{mg} \mathrm{kg}^{-1}\right)$ [17], $16.68 \mathrm{ng} \mathrm{g}^{-1}$ for dimethoate [25]. The spatial distribution of OPPs were not same at all sites. Among stations the highest concentration for OPPs were found at Kuala Terla ranging from $4.6-15 \mu \mathrm{g} \mathrm{kg}^{-1}$ where dimethoate accounted the most indicating its extensive use over the vegetables. The lowest concentration of OPPs were found at Telom region ranging from $\mathrm{ND}-0.02 \mu \mathrm{g} \mathrm{kg}^{-1}$. 
The sum of $\Sigma$ PYRs concentration were $7.9 \pm 12.7 \mu \mathrm{g} \mathrm{kg}^{-1}, 7.9 \pm 15.1 \mu \mathrm{g} \mathrm{kg}^{-1}, 3.6 \pm 14.2 \mu \mathrm{g} \mathrm{kg}^{-1}, 1.3 \pm 2.7 \mu \mathrm{g} \mathrm{kg}^{-1}$, $1.3 \pm 1.6 \mu \mathrm{g} \mathrm{kg}^{-1}, 10.8 \pm 1.1 \mu \mathrm{g} \mathrm{kg}^{-1}$ and $2.7 \pm 12.4 \mu \mathrm{g} \mathrm{kg}^{-1}$ in the soil of crops cabbage, cauliflower, spinach, celery, lettuce, broccoli and mustard showing that the sum of residual concentration is same in cabbage and cauliflower soil and in celery and lettuce (Table 4). The total concentration of PYRs (sum of permethrin and fenvelerate) for soil ranges between ND $-1.3 \mu \mathrm{g} \mathrm{kg}^{-1}$ in cabbage, $\mathrm{ND}-1.3 \mu \mathrm{g} \mathrm{kg}^{-1}$ in celery, $\mathrm{ND}-0.6 \mu \mathrm{g} \mathrm{kg}^{-1}$ in lettuce, $\mathrm{ND}-6.6 \mu \mathrm{g}$ $\mathrm{kg}^{-1}$ in cauliflower, ND $-5.3 \mu \mathrm{g} \mathrm{kg}^{-1}$ in broccoli, $\mathrm{ND}-6.6 \mu \mathrm{g} \mathrm{kg}^{-1}$ in spinach and ND $-1.3 \mu \mathrm{g} \mathrm{kg}^{-1}$ in mustard. The observed trend of concentration studied for PYRs were fenvelerate $(62.2 \%)>$ permethrin $(37.7 \%)$. This does indicate the usage of pyrethroids pesticides in Cameron Highlands as already been reported [8]. PYRs seemed to be the least detected pesticides among all sites indicating its less use in study area. However, the highest concentration was found at Kuala Terla of which fenvelerate accounted the most $\left(10 \mu \mathrm{g} \mathrm{kg}^{-1}\right)$.

Table 4. Concentration of OPPs \& PYRs pesticide in agricultural soil of Cameron Highlands

\begin{tabular}{lccccccc}
\hline \multirow{2}{*}{ Compounds } & \multicolumn{7}{c}{ Concentration in Soil Sample of Vegetables $\left(\boldsymbol{\mu g} \mathbf{~ k g}^{-\mathbf{1}}\right)$} \\
\cline { 2 - 8 } & Cabbage & Cauliflower & Spinach & Celery & Lettuce & Broccoli & Mustard \\
\hline Dimethoate & $6.6 \pm 1.8$ & $6.6 \pm 3.55$ & $26.6 \pm 0.81$ & $0.6 \pm 3.2$ & $0.06 \pm 3.49$ & $20 \pm 1.76$ & $0.6 \pm 5.7$ \\
Diazinon & $20 \pm 1.1$ & $13.3 \pm 2.2$ & $20 \pm 1.8$ & $0.6 \pm 5.6$ & $0.06 \pm 3.8$ & ND & $0.6 \pm 0.9$ \\
Parathion methyl & $0.6 \pm 1.6$ & $0.6 \pm 1.78$ & $1.3 \pm 3.67$ & $0.2 \pm 2.4$ & $0.2 \pm 2.4$ & $1.3 \pm 3.4$ & $1.46 \pm 1.1$ \\
Parathion ethyl & $9.3 \pm 1.27$ & $9.3 \pm 1.54$ & $6.6 \pm 5.6$ & $8 \pm 3.5$ & $3.3 \pm 2.75$ & $20 \pm 1.4$ & $8.6 \pm 3.55$ \\
Chlorpyriphos & $4.6 \pm 0.3$ & $4.6 \pm 0.49$ & $5.3 \pm 1.51$ & $5.3 \pm 4.8$ & $5.3 \pm 0.5$ & $5.3 \pm 5$ & $3.3 \pm 1.24$ \\
Malathion & $4 \pm 1.13$ & $0.4 \pm 0.78$ & $6 \pm 0.3$ & $8 \pm 0.3$ & $6.6 \pm 3.6$ & $11 \pm 6.2$ & $0.66 \pm 6.5$ \\
$\boldsymbol{\Sigma}$ OPPs & $45.1 \pm 7.2$ & $34.8 \pm 10.34$ & $65.8 \pm 2.3$ & $22.7 \pm 19.8$ & $15.5 \pm 16.4$ & $57.6 \pm 17.76$ & $14.6 \pm 19.0$ \\
Permethrin & $1.3 \pm 5.8$ & $1.3 \pm 7.5$ & $0.26 \pm 4.9$ & $1.3 \pm 2.67$ & $1.3 \pm 1.56$ & $6 \pm 1.09$ & $2 \pm 3.5$ \\
Fenvelerate & $6.6 \pm 6.9$ & $6.6 \pm 7.6$ & $3.3 \pm 9.3$ & ND & ND & $4.8 \pm 1.3$ & $0.66 \pm 8.9$ \\
$\boldsymbol{\Sigma}$ PY & $7.9 \pm 12.7$ & $7.9 \pm 15.1$ & $3.5 \pm 14.2$ & $1.3 \pm 2.67$ & $1.3 \pm 1.56$ & $10.8 \pm 2.3$ & $2.6 \pm 12.4$ \\
\hline
\end{tabular}

*ND $=$ not detected

\section{Human health risk assessment for OPPs and PYRs}

In this study we included adults of 70 years old and children of 12 years of age exposed for all the days in a year during their life span. The estimated LADD of total OPPs for adults and children through soil ranged between $6.9 \mathrm{x}$ $10^{-9}-3.6 \times 10^{-7} \mathrm{mg} \mathrm{kg}^{-1} \mathrm{~d}^{-1}$ and $3.6 \times 10^{-8}-1.8 \times 10^{-6} \mathrm{mg} \mathrm{kg}^{-1} \mathrm{~d}^{-1}$ (Table 5). HQ of OPPs for human adults was $5.7 \mathrm{x}$ $10^{-6}, 1.6 \times 10^{-5}, 3.8 \times 10^{-7}, 3.3 \times 10^{-6}, 2.5 \times 10^{-8}, 6.9 \times 10^{-7}$, while for children was $3 \times 10^{-5}, 8 \times 10^{-5}, 1.9 \times 10^{-6}, 1.7 \times$ $10^{-5}, 1.3 \times 10^{-7}, 3.5 \times 10^{-6}$ (Table 5) which were lower than the acceptable risk levels indicating that the daily dose is below the proposed guide lines of USEPA 2012 [12]. For PYRs the LADD adults ranges as $3.7 \times 10^{-9}-3.4 \times 10^{-8}$ $\mathrm{mg} \mathrm{kg}-1 \mathrm{~d}^{-1}$ and for children as $6 \times 10^{-9}-1.7 \times 10^{-8} \mathrm{mg} \mathrm{kg}^{-1} \mathrm{~d}^{-1}$ with the mean values as $7 \times 10^{-9} \mathrm{mg} \mathrm{kg}^{-1} \mathrm{~d}^{-1}$ and $1.7 \mathrm{x}$ $10^{-8} \mathrm{mg} \mathrm{kg}^{-1} \mathrm{~d}^{-1}$. The HQ by fenvelerate and permethrin for adults is $2.2 \times 10^{-7}, 5.4 \times 10^{-8}$ and for children is $1 \times 10^{-6}$, $2.8 \times 10^{-7}$ (Table 6). 
Table 5. Concentration of OPPs and PYRs and its life time average daily dose for humans through soil ingestion

\begin{tabular}{lcccccc}
\hline \multirow{2}{*}{ Compound } & \multicolumn{2}{c}{$\begin{array}{c}\text { Concentration } \\
\left(\mu \mathbf{~ k g}^{-1}\right)\end{array}$} & \multicolumn{4}{c}{ Adults } \\
\cline { 2 - 6 } & Range & Mean & Range & Mean & Range & Mean \\
\hline Dimethoate & $0.06-200$ & 8.0 & $8.6 \times 10^{-11}-2.9 \times 10^{-7}$ & $1.1 \times 10^{-8}$ & $4.4 \times 10^{-10}-1.5 \times 10^{-6}$ & $5.9 \times 10^{-8}$ \\
Diazinon & $0.6-23$ & 7.7 & $8.5 \times 10^{-10}-3.3 \times 10^{-8}$ & $1.1 \times 10^{-8}$ & $4.4 \times 10^{-9}-1.7 \times 10^{-7}$ & $5.7 \times 10^{-8}$ \\
ParathionMethyl & $0.2-12$ & 0.8 & $2.8 \times 10^{-13}-1.7 \times 10^{-8}$ & $1.1 \times 10^{-9}$ & $1.5 \times 10^{-9}-8.9 \times 10^{-8}$ & $6.0 \times 10^{-9}$ \\
Parathion Ethyl & $0.2-10$ & 9.3 & $3.0 \times 10^{-10}-1.4 \times 10^{-8}$ & $1.3 \times 10^{-8}$ & $1.5 \times 10^{-9}-7.4 \times 10^{-8}$ & $6.9 \times 10^{-8}$ \\
Malathion & $2-3$ & 5.2 & $2.9 \times 10^{-9}-4.2 \times 10^{-9}$ & $7.4 \times 10^{-9}$ & $1.5 \times 10^{-8}-2.2 \times 10^{-8}$ & $3.8 \times 10^{-8}$ \\
Chlorpyriphos & $1.8-5.3$ & 4.8 & $2.6 \times 10^{-9}-7.6 \times 10^{-9}$ & $6.8 \times 10^{-9}$ & $1.3 \times 10^{-8}-3.9 \times 10^{-8}$ & $3.5 \times 10^{-8}$ \\
Total OPPs & $4.9-253.3$ & 35.8 & $6.9 \times 10^{-9}-3.6 \times 10^{-7}$ & $5.1 \times 10^{-8}$ & $3.6 \times 10^{-8}-1.8 \times 10^{-6}$ & $2.7 \times 10^{-7}$ \\
Fenvelerate & $0.6-2$ & 3.1 & $9.0 \times 10^{-10}-3.0 \times 10^{-8}$ & $4.3 \times 10^{-9}$ & $4.4 \times 10^{-9}-1.5 \times 10^{-8}$ & $2.3 \times 10^{-8}$ \\
Permethrin & $0.2-0.4$ & 1.9 & $3.0 \times 10^{-10}-6 \times 10^{-10}$ & $2.7 \times 10^{-9}$ & $1.5 \times 10^{-9}-3 \times 10^{-9}$ & $1.4 \times 10^{-8}$ \\
Total PY & $0.8-0.6$ & 5.0 & $3.7 \times 10^{-9}-3.4 \times 10^{-8}$ & $7.0 \times 10^{-9}$ & $6.0 \times 10^{-9}-1.7 \times 10^{-8}$ & $3.7 \times 10^{-8}$ \\
\hline
\end{tabular}

Table 6. Hazard quotients to humans due to OPPs and PYRs

\begin{tabular}{lclllll}
\hline \multirow{2}{*}{ Pesticide } & $\begin{array}{c}\text { Reference dose } \\
\left(\mathbf{m g ~ k g} \mathbf{~ g}^{-1}\right)\end{array}$ & \multicolumn{2}{c}{ LADD $\left(\mathbf{m g ~ k g}^{-1} \mathbf{d}^{-1}\right)$} & \multicolumn{2}{c}{ Hazard Quotient } & \multirow{2}{*}{ Health Risk } \\
\cline { 3 - 6 } & $2 \times 10^{-3}$ & $1.1 \times 10^{-8}$ & $5.9 \times 10^{-8}$ & $5.7 \times 10^{-6}$ & $3 \times 10^{-5}$ & No \\
Dimethoate & $7 \times 10^{-4}$ & $1.1 \times 10^{-8}$ & $5.7 \times 10^{-8}$ & $1.6 \times 10^{-5}$ & $8 \times 10^{-5}$ & No \\
Diazinon & $3 \times 10^{-3}$ & $1.1 \times 10^{-9}$ & $6.0 \times 10^{-9}$ & $3.8 \times 10^{-7}$ & $1.9 \times 10^{-6}$ & No \\
Parathion Methyl & $4 \times 10^{-3}$ & $1.3 \times 10^{-8}$ & $6.9 \times 10^{-8}$ & $3.3 \times 10^{-6}$ & $1.7 \times 10^{-5}$ & No \\
Parathion Ethyl & $3 \times 10^{-1}$ & $7.4 \times 10^{-9}$ & $3.8 \times 10^{-8}$ & $2.5 \times 10^{-8}$ & $1.3 \times 10^{-7}$ & No \\
Malathion & $1 \times 10^{-2}$ & $6.8 \times 10^{-9}$ & $3.5 \times 10^{-8}$ & $6.9 \times 10^{-7}$ & $3.5 \times 10^{-6}$ & No \\
Chlorpyriphos & $2 \times 10^{-2}$ & $4.3 \times 10^{-9}$ & $2.3 \times 10^{-8}$ & $2.2 \times 10^{-7}$ & $1.1 \times 10^{-6}$ & No \\
Fenvelerate & $5 \times 10^{-2}$ & $2.7 \times 10^{-9}$ & $1.4 \times 10^{-8}$ & $5.4 \times 10^{-8}$ & $2.8 \times 10^{-7}$ & No \\
Permethrin & & & & & & \\
\hline
\end{tabular}

\section{Relationship of soil properties with pesticides residue}

The soil samples were analyzed for three physico-chemical properties including texture, $\mathrm{pH}$, and organic carbon content (Table 7). These parameters are important in order to study the mobility and degradation behavior of pesticides. Soil properties influence the fate of the pesticides in soil e.g. the organic content of soil, clay content and the soil $\mathrm{pH}$. As increase in organic content increases the binding forces by bonding with the hydrophobic compounds in the soil thus reducing their mobility. This correlation among the residue of pesticides and soil properties is shown by a biplot (Figure 2) by using the PCA, which is a powerful tool for pattern recognition, classification and modeling and other aspects of data evaluation. It was performed on data of pesticides in soil under study showing the relationship among 17 variables.

Table 7. Physico-chemical properties of soil

\begin{tabular}{ccccc}
\hline \multicolumn{3}{c}{ Textures (\%) } & \multirow{2}{*}{ pH } & Organic Carbon (\%) \\
\cline { 1 - 4 } Coarse Sand & Fine sand & Clay and Silt & & \\
\hline 68 & 17 & 12 & $7-8$ & 17.6 \\
\hline
\end{tabular}


Four principal components with Eigen value $>1$ accounts for $98 \%$ of total variance sets show a high residual concentration of pesticides in soil of brassica vegetables like cabbage, cauliflower, broccoli as compared to other leafy vegetable. Secondly TOC and $\mathrm{pH}$ are not separated by larger distance and are more correlated with DDT, DDD, DDE, endosulfan, $\propto-\mathrm{HCH}$, permethrin, diazinon, chloripyrphos and diazinon in the soils of brassica vegetables like cabbage, cauliflower and broccoli and it also shows that the organic content and $\mathrm{pH}$ of the soil is more correlated with the soils of these crops as compared to other leafy vegetables (mustard, celery and lettuce) thus reducing pesticides mobility due to strong hydrophobic interactions [26]. This shows that the amount of pesticides usage depends upon crop type; the soil of brassica leafy vegetables is more contaminated and it might be possible that these vegetables has the ability to accumulate more OCPs because of the roots of these vegetables exudes organic compounds consisting of 20-30\% of photosynthetic compounds which supports pesticides movement [27] while the decrease in the soil concentration of other leafy vegetables is due to in situ biomass burning during harvesting time of crop cultivation that favors the volatilization of these OCPs [10].

There can be several factors contributing in these observations of these high residual content in brassica vegetables which can be due to a close cultivation of these vegetables in the small field or the procedures used by the farmers for crop protection would be similar for these plants in case of other leafy vegetables the less association of soil with pesticides residues might be because rapid disappearance of pesticides after application or the high rotation frequency of unproductive culture before completely grown [1]. There can also be a possibility that the roots of these vegetables release dehydrohalogenase enzymes that dechlorinate the organohalogenated compounds or there can be enhance degradation due to rhizosphere effect which is the influence of the root system on uptake of contaminants via soil [27]. Biplot also shows a strong correlation between $\mathrm{pH} 7-8$, and organic content (14\%) with the OCPs like DDT, endosulfan and HCHs showing a hydrophobic interaction between the soil particles and pesticides. This indicates a strong pesticide-soil organic interaction masking the acidity and alkalinity of soil [28].

There is not a significant correlation between most of the OPPs with $\mathrm{pH}$ and organic content of soil except diazinon indicating that adsorption of polar OPPs decreases with increase $\mathrm{pH}(7-8)$. However, endosulfan showed a significant correlation indicating that higher $\mathrm{pH}$ is favoured for adsorption of neutral pesticides in soil. These results are similar to the studies reported by Krishna and Philip [29] that pesticides adsorption is maximum between $\mathrm{pH}$ 28. In this case the persistence of these OPPs in the soil of these crops might be due to its adsorption on the clay fraction of soil because of its polar nature as clay particles has a small size and its combination with the organic content is useful because both of these are associated of their mutual interaction of molecular attraction and surface charges [30]. It might also be possible that inhibition of microbial degradation is responsible for holding these pollutants in soil rather than the organic content. It is also had been proved by other studies that in case if polar pesticides are not correlated with the organic content of soil than it has the ability to relate with other factors of soil such as inorganic matter, calcium concentration cation exchange capacity [30,31]. There is also a possibility that under the influence of roots of the brassica vegetables has the ability to facilitate the movements of these chemicals from soil towards the rhizosphere soil from where they are taken up by the roots [32], that is why these vegetables have high concentration of pesticides.

Biplot also indicates that mixture of pesticides has been used on crops and that might also influence the persistence of these pesticides [25]. Diazinon is an exceptional to other OPPs as it seemed to be more correlated with the organic content and $\mathrm{pH}$ of soil showing that at high $\mathrm{pH}$ diazinon is more persistent than other OPPs and it has also more association with organic content that's why cannot be broken easily by water thus cannot be removed by leaching [30,33]. This is in agreement reported previously by Chapman and Cole [28] that maximum correlation of diazinon and chlorpyriphos at high $\mathrm{pH}$. This high correlation of diazinon and chlorpyriphos as compared to other OPPs might also be because of increased difficulty to access the adsorption sites of soil by other pesticides due to increased concentration [34], this increased sorption correlates with the sorption studies [35], suggesting the high sorption based on organic content and the $\mathrm{k}_{\mathrm{ow}}$ of these pesticides. In the case of pyrethroids, permethrin is more correlated with the organic content in these vegetable soils as compared to fenvelerate showing its adsorption with the organic content this correlate with the studies of other researchers [9]. Biplot also indicates that pesticides are originating from different sources as farmers use mixture of pesticides to have more residual effect. 


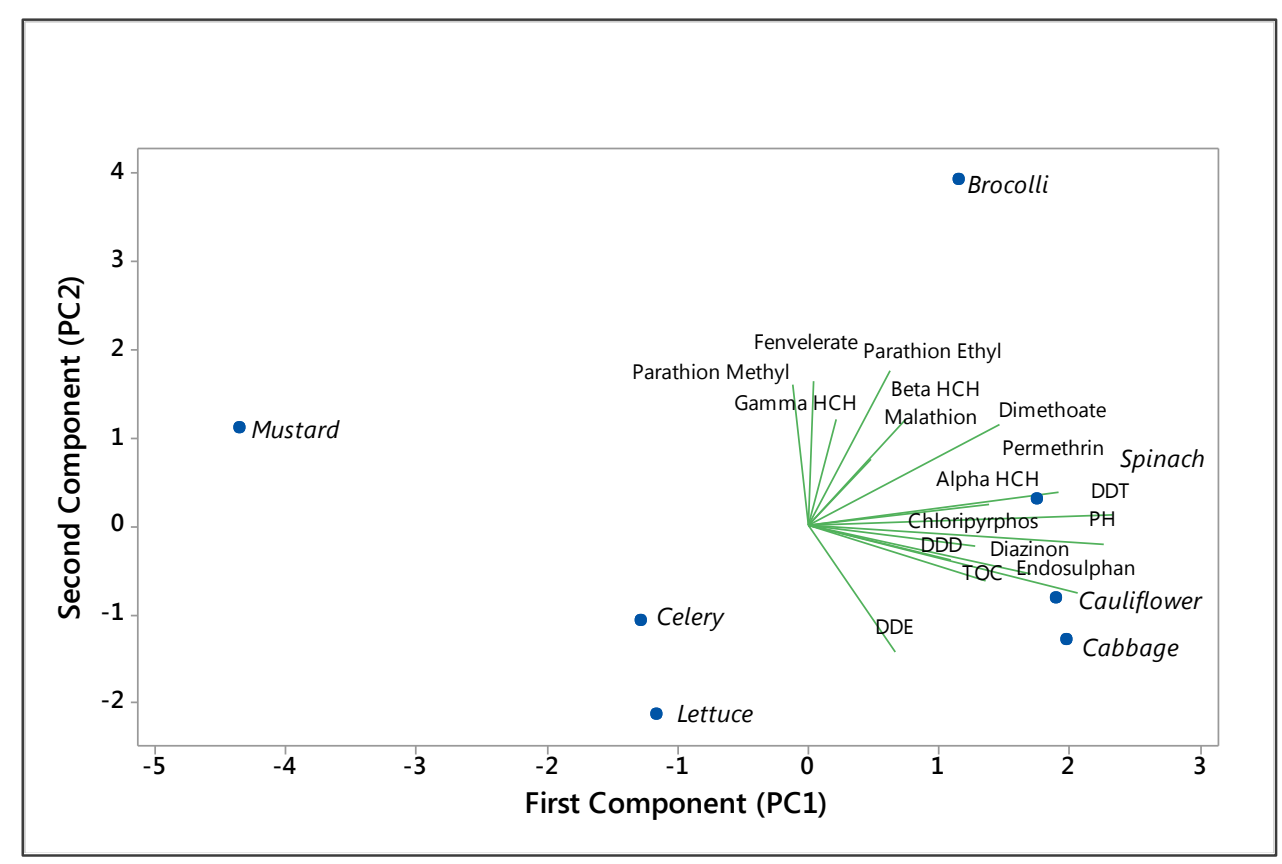

Figure 2. Biplot of two component loading (PC1 x PC2)

\section{Conclusion}

Despite restriction on OCPs, the residues of these pesticides were found in the agricultural soil of Cameron Highlands. The average highest concentration of DDT and $\gamma-\mathrm{HCH}$ indicates the presence of both new and historical input sources for HCHs while historical inputs for DDTs contamination or its slow degradation. The highest concentration for OCPs in soil of these crops were seen as cauliflowers > cabbage > broccoli > celery > lettuce > mustard. The OPPs concentration were higher indicating its continuous use in soil of these crops following order as spinach $>$ cabbage $>$ broccoli $>$ cauliflower $>$ celery $>$ lettuce $>$ mustard. Among PYRs, permethrin was used in high concentration and in soil crops its concentration follows as following order broccoli > cabbage $>$ cauliflower $>$ spinach $>$ celery $>$ lettuce $>$ mustard. These results also show that the farmers prefer to use mixture of these pesticides as they believe it is more effective than using a single kind. PCA shows high residual concentration in soil of brassica vegetables and indicated that the presence of these pesticides in the soil is more correlated with type of crop, its cycle or crop protection and it also shows that most of OCPs and permethrin was more correlated with the total organic content and $\mathrm{pH}$ of soil. Meanwhile in some cases OPPs and fenvelerate were not as correlated with the $\mathrm{pH}$ and organic content indicating its less adsorption on the organic content of soil. The health risk assessment showed that though residues of these contaminants were found in these soil during both less and high frequent spraying by farmers but it poses no health risks to humans working in this agricultural region as the HQs were less than one $(\leq 1)$.In conclusion it is noteworthy to remark that soil total organic content has reduced the mobility for most of the pesticides in the soil of brassica vegetables (cabbage, cauliflower, broccoli) as it has effect on the leachability, biodegradability, volatility, persistence and bioactivity of these pesticides.

\section{Acknowledgement}

Authors wish to thank the Government of Malaysia for grant FRGS/2/2013/STO1/UKM/01/2 and Universiti Kebangsaan Malaysia for DPP-2015-053. Technical help from the Centre of Water Research and Analysis (ALIR) and the School of Chemical Sciences and Food Technology is gratefully acknowledged. We wish to thank the Higher Education Commission, Pakistan for the award of scholarship and Sardar Bahadur Khan Women University (SBKWU), Quetta, Pakistan for study leave. 


\section{References}

1. Gonçalves, C., Da Silva, J. C. E. and Alpendurada, M. F. (2006). Chemometric interpretation of pesticide occurrence in soil samples from an intensive horticulture area in North Portugal. Analytica Chimica Acta, 560: $164-171$.

2. Mishra, K., Sharma, R. C. and Kumar, S. (2012). Contamination levels and spatial distribution of organochlorine pesticides in soils from India. Ecotoxicology Environment Safety, 76: 215 - 225.

3. Shi, R., Lv, J. and Feng, J. (2011). Assessment of pesticide pollution in suburban soil in South Shenyang, China. Bulletin of Environmental Contamination and Toxicology, 87: 567 - 573.

4. El-Shahawi, M. S., Hamza, A., Bashammakh, A. S. and Al-Saggaf, W.T. (2010). An overview on the accumulation, distribution, transformations, toxicity and analytical methods for the monitoring of persistent organic pollutants. Talanta, 80:1587 - 1597.

5. Ng, W. F., Teo, M. J. K. and Lakso, H. A. (1999). Determination of organophosphorus pesticides in soil by headspace solid-phase microextraction. Fresenius' Journal of Analytical Chemistry, 363: 673 - 679.

6. Derbalah, A. S., Ismail, A. and Hamza, A. (2013). Monitoring of organophosphorus pesticides and bioremediation chlorpyrifos in soil. Egyptian Journal of Plant Production Research, 1: 115 - 132.

7. Sattar M. A. (1990). Fate of organophosphorus pesticides in soils. Chemosphere, 20: 387 - 396.

8. Ragnarsdottir, K. V. (2000). Environmental fate and toxicology of organophosphate pesticides. Journal of the Geological Society, 157: 859 - 876.

9. Ismail, B. S. and Kalithasan, K. (2004). Adsorption, desorption, and mobility of permethrin in Malaysian soils. Journal of Environmental Science and Health Part B, 39: 419 - 429.

10. Velasco, A., Hernández, S., Ramírez, M. and Ortíz, I. (2014). Detection of residual organochlorine and organophosphorus pesticides in agricultural soil in Rio Verde Region of San Luis Potosi, Mexico. Journal of Environmental Science and Health, Part B: Pesticides, Food Contaminants, and Agricultural Wastes, 49: 498 504.

11. Gao F., Jia, J. and Wang, X. (2008). Occurrence and ordination of dichlorodiphenyltrichloroethane and hexachlorocyclohexane in agricultural soils from Guangzhou, China. Archives of Environmental Contamination and Toxicology, 54:155 - 166 .

12. Bempah, C. K., Donkor, A., Yeboah, P. O., Dubey, B. and Osei-Fosu, P. (2011). A preliminary assessment of consumer's exposure to organochlorine pesticides in fruits and vegetables and the potential health risk in Accra Metropolis, Ghana. Food Chemistry, 128: 1058 - 1065.

13. Kumar, B., Verma, V.K., Mishra, M., Gaur, R., Kumar, S. and Sharma, C.S. (2014). DDT and HCH (Organochlorine Pesticides) in residential soils and health assessment for human populations in Korba, India. Human and Ecological Risk Assessment: An International Journal, 20: 1538 - 1549.

14. Arias-Estévez M., López-Periago, E., Martínez-Carballo, E., Simal-Gándara, J., Mejuto, J. C. and García-Río, L. (2008). The mobility and degradation of pesticides in soils and the pollution of groundwater resources. Agriculture, Ecosystems \& Environment, 123: 247 - 260.

15. Weng, T. K. and Chee, B. W. (2015). Water quality monitoring using biological indicators in Cameron Highlands Malaysia. Journal of Sustainable Development, 8: 28 - 42.

16. Heiri, O., Lotter, A. F. and Lemcke, G. (2001). Loss on ignition as a method for estimating organic and carbonate content in sediments: Reproducibility and comparability of results. Journal of Paleolimnology, 25: $101-110$.

17. Ngan, C. K., Cheah, U. B., Abdullah, W. W., Lim, K. P. and Ismail, B. S. (2005). Fate of chlorothalonil, chlorpyrifos and profenofos in a vegetable farm in Cameron Highlands, Malaysia. Water, Air, \& Soil Pollution: Focus, 5:125-136.

18. Agency for Toxic substances and Disease Registry (2005). Toxicological profile for hexachlrocyclohexanes. US Public Health Service, Atlanta, GA, USA.

19. United States Environmental Protection Agency (1989). Risk assessment guide for super fund. Human health evaluation manual, Part A. EPA 540-1-89-002.USEPA, Washington DC.

20. Shukor, N. S. A., Khazaai, S. N. M., Hussain, Z. M. and Jan, S. L. M. (2015). Degradation behavior of chlorpyrifos in spinach (Spinacia oleracea) and soil. Malaysian Journal of Analytical Sciences 19(4), 722 729. 
21. Velasco, A., Rodríguez, J., Castillo, R. and Ortíz, I. (2012). Residues of organochlorine and organophosphorus pesticides in sugarcane crop soils and river water. Journal of Environmental Science and Health, Part B: Pesticides, Food Contaminants, and Agricultural Wastes, 47: 833 - 841.

22. Miglioranza, K. S. B., de Moreno, J. E., Moreno, V. J., Osterrieth, M. L. and Escalante, A. H. (1999). Fate of organochlorine pesticides in soils and terrestrial biota of "los padres" pond watershed, Argentina. Environmental Pollution, 105: 91 - 99.

23. Gonzalez, M., Miglioranza, K. S., Aizpún de Moreno J. E. and Moreno, V. J. (2003). Organochlorine pesticide residues in leek (Allium porrum) crops grown on untreated soils from an agricultural environment. Journal Agricultural and Food Chemistry, 51: 5024 - 5029.

24. Vig, K., Singh, D. K., Agarwal, H. C., Dhawan, A. C. and Dureja, P. (2001). Insecticide residues in cotton crop soil. Journal of Environmental Science and Health, Part B: Pesticides, Food Contaminants, and Agricultural Wastes, 36: 421 - 434.

25. Crisanto, T., Sanchez-Martin, M. J., Sanchez-Camazano, M. and M. Arienzo (1994). Mobility of pesticides in soils. influence of soil properties and pesticide structure. Toxicological \& Environmental Chemistry, 45: 97 104.

26. Gonzalez, M., Miglioranza, K. S., Aizpún, J. E., Isla, F. I. and Peña, A. (2010). Assessing pesticide leaching and desorption in soils with different agricultural activities from Argentina (Pampa and Patagonia). Chemosphere, 81: $351-358$.

27. Pereira, R. C., Camps-Arbestain, M., Garrido, B. R., Macías, F. M. and Monterroso, C. (2006). Behaviour of $\alpha-, \beta-, \gamma-$, and $\delta$-Hexachlorocyclohexane in the soil-plant system of a contaminated site. Environmental Pollution, 144: 210 - 217.

28. Chapman, R. A. and Cole, C. M. (1982). Observations on the influence of water and soil pH on the persistence of insecticides. Journal of Environmental Science \& Health Part B, 17: 487 - 504.

29. Krishna, K. R. and Philip, R. (2008). Adsorption and desorption characteristics of lindane, carbofuran and methyl parathion on various Indian soils. Journal of Hazardous Materials 160: 559 - 567.

30. Vagi, M. C, Petsas, A. S., Kostopoulou, M. N. and Lekkas, T. D. (2010). Adsorption and desorption processes of the organophosphorus pesticides, dimethoate and fenthion, onto three Greek agricultural soils. International Journal of Environmental and Analytical Chemistry, 90: 369 - 389.

31. Rodriguez-Cruz, M. S., Sanchez-Martin, M. J. Andrades, M. J. and Sánchez-Camazano, M. (2006). Comparison of pesticide sorption by physicochemically modified soils with natural soils as a function of soil properties and pesticide hydrophobicity. Soil and Sediment Contamination, 15:401 - 415.

32. Tao, S., Xu, F. L., Wang, X. J., Liu, W. X., Gong, Z. M. and Fang, J.Y. (2005). Organochlorine pesticides in agricultural soil and vegetables from Tianjin, China. Environmental Science \& Technology, 39(8): 2494 - 2499.

33. Getzin, L. W. (1968). Persistence of diazinon and zinophos in soil: Effects of autoclaving, temperature, moisture, and acidity. Journal of Economic Entomology, 61: 1560 - 1565.

34. Nemeth-Konda, L., Füleky, G., Morovjan, G. and Csokan, P. (2002). Sorption behaviour of acetochlor, atrazine, carbendazim, diazinon, imidacloprid and isoproturon on Hungarian agricultural soil. Chemosphere, 48: $545-552$.

35. Kanazawa, J. (1989). Relationship between the soil sorption constants for pesticides and their physicochemical properties. Environmental Toxicology and Chemistry, 8: 477 - 484. 